\title{
A mixed-methods approach to assessing success in transitioning water management institutions: a case study of the Platte River Basin, Nebraska
}

\author{
Christina Hoffman Babbitt $^{1}$, Mark Burbach $^{1}$ and Lisa Pennisi $^{1}$
}

\begin{abstract}
To address increasing conflicts between surface water and groundwater users, the state of Nebraska has adopted a more localized and integrated approach in managing water resources. Integrated approaches offer promise in better managing connected water resources within the state; however, little review of the potential benefits and/or challenges of these actions has been conducted. This case study uses both qualitative and quantitative data collection efforts to take an in-depth look at how this new and innovative management system is working through the eyes of stakeholders living and working in the basin. Data collection reveals that overall the current water management system is working relatively well, even though it is still in its infancy. However, the system could be further improved by ensuring all that stakeholder interests are represented, providing increased opportunities to participate, and continuing to work toward more holistic and proactive water management.
\end{abstract}

Key Words: common pool resources; governance; integrated water resources management; mixed-methods research

\section{INTRODUCTION}

Within Nebraska, increasing demands for water resources, emerging conflicts between water users, mounting concerns over threatened and endangered species, and obligations to abide by interstate water allocation agreements have motivated the state to revisit traditional approaches toward water management. Consequently, Nebraska's water institutions, which we define as both the formal and informal practices that structure human interactions, including established rules, laws, organizational entities, norms, and codes of conduct (Armitage et al. 2007), have undergone significant change over the past several decades. Nebraska's water institutions have evolved from a system of statecontrolled water resources to a system of divided state and local control, and finally, in certain situations, to a more integrated system of shared state and local control. This recently developed governance structure, which is unique to Nebraska, takes a new and innovative approach to how water resources are managed. However, although more localized and integrated water management approaches offer promise in better managing interconnected water resources, little review of how the current system is actually working exists.

As new institutional arrangements are devised to manage water resources, efforts are required to assess the effectiveness of these novel arrangements. Innovations in rules is often a trial-and-error process that usually requires more than one round to get the rules right (Ostrom 1998, 1990). Management strategies and policies are experiments (Lee 1993), and in conducting such experiments, it is essential to learn from institutional change to ensure water managers and policy makers are getting the rules right.

One theoretical basis from which to pursue such research is through the lens of established principles of successful commonpool resource (CPR) governance. Elinor Ostrom (1990) defined several characteristics or "principles" descriptive of local communities that developed successful management institutions that allow individuals to achieve long-term productive outcomes in managing CPRs. CPRs such as water have two defining characteristics: it is difficult to exclude beneficiaries from using the resource and use of the resource by one person or group reduces resource availability for others (Poteete et al. 2010). Ostrom's principles characteristic of institutional success include (1) clearly defined boundaries, (2) congruence between appropriation and provision rules and local conditions, (3) collective-choice arrangements, (4) monitoring, (5) graduated sanctions, (6) conflict-resolution mechanisms, (7) minimal recognition of rights to organize, and (8) nested enterprises (Ostrom 1990:90).

Ostrom's design principles, which overlap with other CPR research efforts (Baland and Platteau 1996, Wade 1998, Pomeroy and McConney 2007), are well known (Folke et al. 2007) and provide a valuable resource that can be used to assess sustainable commons (Ostrom et al. 1999, Berkes 2007). However, the current knowledge base for assessing institutional success is most strongly established for small-scale ecologies and institutions where long time-series studies on many successes and failures exist (Dietz et al. 2003). Although these principles are nonetheless well established as a result of empirical studies and appear to be applicable at larger scales (Dietz et al. 2003, Anderies et al. 2004), there is a need to develop diagnostic methods to identify combinations of variables that affect the incentives and actions of actors under diverse, and arguably more complex, large-scale governance systems (Ostrom 2007). Increasing populations, consumption, and advancing technologies for resource use (Dietz et al. 2003), combined with changing markets and state policies (Agrawal 2001), continually influence management efforts and outcomes, prompting a need to revisit the characteristics that drive institutional success.

Although the real measure of the success of any water management institution depends on how well the institution manages the resource over the long term, waiting decades to see the results of management actions is not an effective or wise strategy. This eliminates any potential to learn from management actions and prohibits improvements and necessary adaptations. Making wise decisions today requires methodologies and initiatives that yield a more immediate determination of whether 
an institution is working. One way to assess whether or not an institution is working, at least in the short term, is to determine whether the people impacted by the institution believe the institution is achieving its management goals. In the minds of stakeholders, the success of an institution often depends on whether that institution measures up to the expectation of what the institution should do. Politically, at least in a democracy, an institution is unlikely to survive over the long term if the majority of stakeholders feel the institution is not accomplishing its intended goals and objectives.

This research had four major goals. The first was to develop and implement a survey instrument to measure how well Nebraska's current water management system is working; the term "working" refers to how well stakeholders perceive Nebraska's current management institutions to be performing, based on a list of institutional success criteria informed by qualitative research and academic literature. The second was to generate insight into the characteristics that either promote or impede successful water resource management within the basin. Third, by assessing a new and unique water management system in an overappropriated river basin in Nebraska, we hoped to add to an understanding of the principles that characterize successful CPR management institutions in a large, complex setting. The term "overappropriated" is used to describe a basin where existing uses of water exceed the available supply of water, resulting in expected declines of both surface and groundwater resources in the designated area (DNR 2005). Finally, we assessed the potential for success of a new and unique institutional framework for water management that could be a model to be used by others states looking to better integrate management of surface water and groundwater resources.

\section{CASE STUDY: THE OVERAPPROPRIATED PORTION OF THE PLATTE RIVER BASIN, NEBRASKA}

Nebraska is considered a state that is rich in both surface water and groundwater resources. However, many of the state's rivers are either fully appropriated or overappropriated (DNR 2009). In an effort to address declining water resources and escalating conflicts between surface and groundwater resource users, Nebraska adopted a more localized and integrated approach in managing interconnected surface water and groundwater resources.

One innovative and unique change was the creation of a comprehensive system of statewide, locally governed management districts, Natural Resources Districts (NRDs), which are charged with diverse natural resource-related management responsibilities, ranging from pollution prevention to development and management of fish and wildlife habitat to management of groundwater within their respective districts. Nebraska's NRDs have been touted as a national model for maintaining local control of natural resources decisions (Mossman 1996). More recently, the state implemented Integrated Management Planning to better manage interconnected surface and groundwater resources. This effort brings together local NRDs charged with managing groundwater and the Nebraska Department of Natural Resources (DNR), a state agency that has authority over surface water resources. Before this initiative, surface water and groundwater resources were managed as separate resources.
This study focuses on how these efforts are working in the overappropriated portion of the Platte River Basin (PRB), which consists of five NRDs: North Platte, South Platte, Central Platte, Twin Platte, and Tri-Basin. Integrated management planning efforts are relatively new within the state, with each of the five PRB NRDs implementing their first Integrated Management Plans (IMPs) in 2009. Although the effort is still in its infancy, an analysis of stakeholders' perspectives on how the system is working can provide valuable feedback to managers and policy makers interested in reviewing progress and challenges to date.

\section{METHODOLOGY}

The research design included a seven-step mixed-methods process to study how well PRB stakeholders perceive water management institutions to be working. Mixed-methods research combines elements of qualitative and quantitative approaches for the purpose of breadth and depth of understanding and corroboration (Johnson et al. 2007). Specifically, we adopted the exploratory sequential design, mixed-methods format, in which researchers first explore the topic through a quantitative study and then use the data collected to inform the second, quantitative phase of the study. The purpose of the exploratory sequential design is to first qualitatively explore with a small sample and then to determine if the qualitative findings generalize to a large sample (Creswell and Plano Clark 2011).

\section{Step 1: Defining the construct}

A list of 15 criteria descriptive of successful water resources management were derived from 2 main sources: Elinor Ostrom's 8 design principles (Ostrom 1990) and qualitative data collection and analysis of 35 stakeholder interviews conducted within the PRB. In addition to Ostrom's 8 established principles, in-depth semistructured interviews were used to gain insight into the characteristics that stakeholders felt were important in successfully managing water resources in the PRB and to explore how well water users believe the current system is working. Interviews included representatives from local, state, and federal water-related agencies, upstream and downstream surface-water appropriators, groundwater users, irrigation districts, and municipal, hydroelectric, industrial, and recreational interests within the basin. Interviews ranged in duration from 30 to 90 minutes and were conducted both in person (33 interviews) and by telephone ( 2 interviews). Interviews were recorded, transcribed verbatim, and subsequently coded and analyzed to search for emerging themes descriptive of characteristics stakeholders felt important to successfully managing the basins water resources. A typological coding methodology was used that requires the researcher to sort data into typological categories to discover patterns and discover themes (Hatch 2002). Codes were then compared across all interview data to search for overlapping trends in meaning and redundancy.

Characteristics derived from analysis of stakeholder interviews, combined with Ostrom's 8 design principles (Ostrom 1990), resulted in a robust list of 15 criteria descriptive of successful water management institutions: (1) an ability to influence rules, (2) clearly defined water-use rules, (3) conflict resolution mechanisms, (4) benefits that outweigh costs, (5) enforcement, (6) equity, (7) flexibility, (8) funding, (9) integration, (10) knowledge, (11) leadership, (12) local control, (13) monitoring, (14) proactive planning, and (15) trust (see Table 1). 
Table 1. Characteristics promoting successful water management.

\begin{tabular}{|c|c|}
\hline Management Criteria & Criteria Description \\
\hline $\begin{array}{l}\text { Ability to Influence } \\
\text { Rules }^{\dagger+}\end{array}$ & $\begin{array}{l}\text { An ability to influence rules through } \\
\text { meaningful and ongoing participation } \\
\text { inclusive of all stakeholder interests. }\end{array}$ \\
\hline $\begin{array}{l}\text { Clearly Defined Water- } \\
\text { Use Rules }{ }^{\dagger \star}\end{array}$ & $\begin{array}{l}\text { Water users must have a clear understanding } \\
\text { of what the water-use rules are and how the } \\
\text { rules apply. }\end{array}$ \\
\hline Conflict Resolution ${ }^{\ddagger}$ & $\begin{array}{l}\text { Mechanisms must be put in place to resolve } \\
\text { conflicts between water users. }\end{array}$ \\
\hline Costs and Benefits ${ }^{\ddagger}$ & $\begin{array}{l}\text { Costs accrued in managing water resources } \\
\text { should be in line with benefits. }\end{array}$ \\
\hline Enforcement ${ }^{\ddagger}$ & $\begin{array}{l}\text { Water users who violate rules should face } \\
\text { graduated sanctions, reflective of the number } \\
\text { of violations committed and seriousness of } \\
\text { the offense. }\end{array}$ \\
\hline Equity $^{\dagger}$ & $\begin{array}{l}\text { Despite differences in how people use and } \\
\text { value water, it is essential that all water users } \\
\text { feel they are treated fairly. }\end{array}$ \\
\hline Flexibility $^{\dagger}$ & $\begin{array}{l}\text { Water institutions must be able to adapt to } \\
\text { changing conditions, have the freedom to } \\
\text { develop and implement innovate solutions, } \\
\text { and learn from new information. }\end{array}$ \\
\hline Funding $^{\dagger}$ & $\begin{array}{l}\text { A stable and sufficient funding source is } \\
\text { essential in developing and sustaining water } \\
\text { management programs, projects, and staff. }\end{array}$ \\
\hline Integration $^{\dagger+}$ & $\begin{array}{l}\text { Integration refers to the connectedness of } \\
\text { water management institutions, both } \\
\text { vertically and horizontally, as well as to the } \\
\text { connectedness of legislation and legal } \\
\text { doctrines devised to govern water resources. }\end{array}$ \\
\hline Knowledge $^{\dagger}$ & $\begin{array}{l}\text { Successful water management involves } \\
\text { understanding the resource system being } \\
\text { managed. Knowledge is reflected in staff } \\
\text { expertise, technology, data monitoring } \\
\text { programs, education and awareness } \\
\text { programs, and an ability to learn. }\end{array}$ \\
\hline Leadership $^{\dagger}$ & $\begin{array}{l}\text { Good leadership involves making difficult } \\
\text { choices that are in the best interest of society } \\
\text { as a whole, providing overarching direction } \\
\text { to constituents, and a willingness to be a part } \\
\text { of the long-term decision-making process. }\end{array}$ \\
\hline Local Control $^{\dagger *}$ & $\begin{array}{l}\text { The ability to develop local solutions } \\
\text { targeted at the specific circumstances of a } \\
\text { particular district or region. }\end{array}$ \\
\hline Monitoring $^{\ddagger}$ & $\begin{array}{l}\text { Monitoring mechanisms are in place so that } \\
\text { the status of the resource, as well as people's } \\
\text { behavior in using the resource, is known and } \\
\text { can be appropriately addressed. }\end{array}$ \\
\hline Proactive Planning $^{\dagger}$ & $\begin{array}{l}\text { Proactive planning involves actively } \\
\text { addressing long-term concerns and issues in } \\
\text { the current planning process. }\end{array}$ \\
\hline Trust $^{\dagger}$ & $\begin{array}{l}\text { Building and establishing relationships so } \\
\text { that there is a greater level of } \\
\text { communication, confidence, and acceptance } \\
\text { in water management actions and initiatives. }\end{array}$ \\
\hline
\end{tabular}

Denotes characteristics derived from in-depth qualitative interviews.

"Denotes Ostrom’s 8 design principles (Ostrom 1990).

Step 2: Item development

Building off qualitative data collection efforts, the 15 established success criteria were then operationalized and incorporated into a self-administered survey. Initially, 5-6 items were developed for each criterion, i.e., success characteristic, using data garnered in qualitative interviews and from a literature review of the relevant success criteria. Items were developed using an 8-point Likert scale, with 0 representing nonagreement and 7 representing strong agreement, with a number assigned to each choice.

Cognitive interviews, also referred to as intense individual interviews, were conducted to test for item comprehension, wording, visual design, and navigation problems in the initial version of the survey tool (Fowler 1995). The cognitive interview process aims to find out how well respondents comprehend questions and perform the response task by asking interviewees to read the survey questions aloud and then explain their thought process as they answer each question (Fowler 1995).

\section{Step 3: Face validity}

As recommended by DeVellis (2003), a panel of judges with expertise in the content area were asked to review the revised survey tool to provide feedback on the relevancy of each item to the phenomenon being measured, the clarity of each item, any items that might need to be reworded, and criteria that require further items to better capture the characteristic being measured. Seven persons with specialized knowledge in the field of water resources management reviewed the survey tool.

\section{Step 4: Q-sort methodology}

The Q-sort method is a cost-effective, straightforward, and powerful method used to assess the reliability and construct validity of questionnaires in a pretesting stage (Nahm et al. 2002, Thomas and Watson 2002). The method tests item agreement and fit to form the basis for assessing construct validity and to improve the reliability of the constructs ( $N a h m$ et al. 2002). Q-sort methodology traditionally involves selecting judges who first sort survey items into corresponding groups for each criterion. The items are typically written on cards and sorted into piles. During the second stage, items that are considered weak or that are categorized incorrectly are reworded or thrown out in an effort to improve item agreement between judges. For this research, a modified Q-sort method was developed and applied to facilitate online application of the method. The online Q-sort survey randomly listed each of the 58 survey items and provided an alphabetical bank of the 15 criteria at the top of each survey page. Next to each item was an 8-point Likert-scale. The Q-sort presurvey instructions first asked each participant to select the principle that best relates to each item and then, using the Likert scale, to rank how well each statement fits with the principle selected. The pretest survey was emailed to a preselected group of water users and management experts within Nebraska. In total, 33 pretest surveys were completed. Items were kept if the correct criterion was matched to the corresponding statement at least $80 \%$ of the time and the statement received a mean goodness of fit score of at least 5.6 , or $80 \%$, on the 8 -point scale. Based on the results of the Q-sort, the highest scoring 3-4 items meeting these conditions were retained for each criterion for a total of 47 remaining items.

\section{Step 5: Survey implementation}

The targeted survey population included both surface water and groundwater users within the PRB. Within Nebraska, surface water and groundwater are administered under two separate systems. As a result, two main sources were used to obtain the 
survey sample population. A list of 14,939 groundwater users within the study region was obtained using a publically available list of registered groundwater wells, along with associated mailing addresses, maintained by the DNR (DNR 2012a).

Obtaining a list of surface water users within the study region was not straightforward. Whereas a list of surface water permit holders is publicly available from the DNR, oftentimes large irrigation and/or canal companies hold the permit, therefore making it more difficult to identify the number of individual users with water rights. Such overarching entities are often unable and/ or unwilling to release information relating to individual water users. Consequently, to best capture surface water user perspectives, a publicly available list of the board of directors from all irrigation and canal companies within the study region was obtained. To be elected to the board of directors, an individual must be a water user. This list was combined with the list of individual surface water right holders maintained by the DNR, not including overarching irrigation and canal companies, to generate a list of 386 surface water user addresses.

Because the available list of surface water users was significantly smaller than the list of groundwater users, the entire population of surface water users was included in the survey population, along with a simple random sample of the 14,939 groundwater users. Because many water users use both surface and groundwater resources, duplicate addresses were eliminated from the population before generating the random sample. Although a random sample of the entire population of both surface water and groundwater users would be optimal, the selected procedure was deemed the best alternative.

The self-administered, anonymous mail survey was implemented following selected procedures recommended by Dillman et al. (2009). Mailed survey packets included a cover letter, two-page survey, and stamped return envelope. One week after the initial survey mailing, a reminder postcard was sent.

\section{Step 6: Scale item reliability}

Once survey responses were complied, a scale item analysis was performed on the survey data to ensure that items formed an internally consistent scale, i.e., that items measured the same construct. Item analysis requires a sample size of approximately 100 to 200 respondents; this survey had 338 respondents.

In choosing which items to retain, Spector (1992) recommends retaining items with the highest item remainder coefficients (corrected item-total correlation) but notes that this is often a balance between retaining coefficients above a set criterion, e.g., 0.4 , and retaining a certain number of items. Field (2009) suggests that corrected item-total correlations should be greater than 0.3 ; correlation values lower than this indicate that the item does not correlate well with the average behavior of the other items and therefore should be discarded. Scale item reliability analysis revealed that all items were above 0.4 (see Table 2).

Cronbach's $\alpha$ is a measure of the internal consistency of the scale, which directly corresponds to both the number of items and their magnitude of intercorrelation (Spector 1992). A widely accepted rule of thumb is that $\alpha$ should be above 0.7 to demonstrate internal consistency (Nunnally 1978). All items had high reliabilities with Cronbach's $\alpha \geq 0.7$ (see Table 2). Based on the results of corrected item-total correlations and Cronbach's $\alpha$, it was decided that all items should be retained.
Table 2. Scale item reliability analysis.

\begin{tabular}{|c|c|c|c|}
\hline \multirow[b]{2}{*}{ Survey Items } & \multicolumn{2}{|c|}{ Item-Total Statistics } & \multirow{2}{*}{$\begin{array}{c}\text { Reliability } \\
\text { Statistics } \\
\text { Cronbach's } \\
\text { Alpha }\end{array}$} \\
\hline & $\begin{array}{c}\text { Corrected } \\
\text { Item-Total } \\
\text { Correlation }\end{array}$ & $\begin{array}{c}\text { Cronbach's } \\
\text { Alpha if item } \\
\text { deleted }\end{array}$ & \\
\hline \multicolumn{4}{|c|}{ Ability to Influence Rules } \\
\hline Item 7 & 0.683 & 0.798 & 0.839 \\
\hline Item 16 & 0.717 & 0.764 & \\
\hline Item 35 & 0.716 & 0.770 & \\
\hline \multicolumn{4}{|c|}{ Clearly Defined Water-Use } \\
\hline Item 5 & 0.672 & 0.825 & 0.854 \\
\hline Item 13 & 0.693 & 0.816 & \\
\hline Item 23 & 0.754 & 0.789 & \\
\hline Item 24 & 0.668 & 0.826 & \\
\hline \multicolumn{4}{|c|}{ Conflict Resolution } \\
\hline Item 10 & 0.602 & 0.762 & 0.794 \\
\hline Item 22 & 0.628 & 0.729 & \\
\hline Item 33 & 0.686 & 0.671 & \\
\hline \multicolumn{4}{|c|}{ Costs and Benefits } \\
\hline Item 12 & 0.513 & 0.829 & 0.788 \\
\hline Item 29 & 0.674 & 0.662 & \\
\hline Item 30 & 0.709 & 0.622 & \\
\hline \multicolumn{4}{|l|}{ Enforcement } \\
\hline Item 20 & 0.691 & 0.743 & 0.822 \\
\hline Item 27 & 0.683 & 0.749 & \\
\hline Item 46 & 0.661 & 0.771 & \\
\hline \multicolumn{4}{|l|}{ Equity } \\
\hline Item 2 & 0.570 & 0.803 & 0.796 \\
\hline Item 18 & 0.641 & 0.723 & \\
\hline Item 39 & 0.718 & 0.637 & \\
\hline \multicolumn{4}{|l|}{ Flexibility } \\
\hline Item 11 & 0.536 & 0.621 & 0.714 \\
\hline Item 21 & 0.535 & 0.623 & \\
\hline Item 45 & 0.528 & 0.631 & \\
\hline \multicolumn{4}{|l|}{ Funding } \\
\hline Item 4 & 0.722 & 0.84 & 0.873 \\
\hline Item 31 & 0.649 & 0.867 & \\
\hline Item 37 & 0.806 & 0.806 & \\
\hline Item 44 & 0.74 & 0.832 & \\
\hline \multicolumn{4}{|l|}{ Integration } \\
\hline Item 17 & 0.798 & 0.852 & 0.897 \\
\hline Item 26 & 0.785 & 0.863 & \\
\hline Item 40 & 0.807 & 0.844 & \\
\hline \multicolumn{4}{|l|}{ Knowledge } \\
\hline Item 9 & 0.446 & 0.782 & 0.723 \\
\hline Item 25 & 0.653 & 0.513 & \\
\hline Item 36 & 0.565 & 0.616 & \\
\hline \multicolumn{4}{|l|}{ Leadership } \\
\hline Item 3 & 0.524 & 0.674 & 0.729 \\
\hline Item 42 & 0.645 & 0.530 & \\
\hline Item 47 & 0.492 & 0.714 & \\
\hline Local Control & & & \\
\hline Item 14 & 0.521 & 0.626 & 0.708 \\
\hline Item 28 & 0.461 & 0.695 & \\
\hline Item 38 & 0.601 & 0.524 & \\
\hline Monitoring & & & \\
\hline Item 6 & 0.566 & 0.706 & 0.760 \\
\hline Item 15 & 0.578 & 0.692 & \\
\hline Item 43 & 0.629 & 0.634 & \\
\hline Proactive Plan & & & \\
\hline Item 1 & 0.680 & 0.729 & 0.814 \\
\hline Item 8 & 0.677 & 0.732 & \\
\hline Item 34 & 0.644 & 0.768 & \\
\hline Trust & & & \\
\hline Item 19 & 0.747 & 0.793 & 0.859 \\
\hline Item 32 & 0.779 & 0.760 & \\
\hline Item 41 & 0.687 & 0.847 & \\
\hline
\end{tabular}


Table 3. Overall distribution and summary statistics for the successful water management in the Platte River Basin, Nebraska, survey criteria. The highest response rate for each criterion is in bold.

\begin{tabular}{|c|c|c|c|c|c|c|c|c|c|c|c|}
\hline \multirow{4}{*}{ Criterion } & \multirow{4}{*}{$\mathrm{N}$} & \multirow{4}{*}{ Mean } & \multirow{4}{*}{$\begin{array}{l}\text { Standard } \\
\text { Deviation }\end{array}$} & \multicolumn{8}{|c|}{ Distribution of Responses } \\
\hline & & & & \multicolumn{6}{|c|}{ I do not agree } & \multicolumn{2}{|c|}{ I strongly agree } \\
\hline & & & & 0 & 1 & 2 & 3 & 4 & 5 & 6 & 7 \\
\hline & & & & $\begin{array}{c}\mathrm{N} \\
(\%)\end{array}$ & $\begin{array}{c}\mathrm{N} \\
(\%)\end{array}$ & $\begin{array}{l}\mathrm{N} \\
(\%)\end{array}$ & $\begin{array}{c}\mathrm{N} \\
(\%)\end{array}$ & $\begin{array}{l}\mathrm{N} \\
(\%)\end{array}$ & $\begin{array}{l}\mathrm{N} \\
(\%)\end{array}$ & $\begin{array}{c}\mathrm{N} \\
(\%)\end{array}$ & $\begin{array}{c}\mathrm{N} \\
(\%)\end{array}$ \\
\hline Ability to Influence Rules & 338 & 2.59 & 1.56 & $\begin{array}{c}33 \\
(10.0)\end{array}$ & $\begin{array}{c}52 \\
(15.4)\end{array}$ & $\begin{array}{c}91 \\
(26.9)\end{array}$ & $\begin{array}{c}65 \\
(19.2)\end{array}$ & $\begin{array}{c}55 \\
(16.3)\end{array}$ & $\begin{array}{c}31 \\
(9.2)\end{array}$ & $\begin{array}{c}9 \\
(2.7)\end{array}$ & $\begin{array}{c}2 \\
(.6)\end{array}$ \\
\hline Clearly Defined Water-Use Rules & 338 & 4.03 & 1.57 & $\begin{array}{c}8 \\
(2.4)\end{array}$ & $\begin{array}{c}14 \\
(4.1)\end{array}$ & $\begin{array}{c}31 \\
(9.2)\end{array}$ & $\begin{array}{c}55 \\
(16.3)\end{array}$ & $\begin{array}{c}85 \\
(25.1)\end{array}$ & $\begin{array}{c}75 \\
(22.2)\end{array}$ & $\begin{array}{c}49 \\
(14.5)\end{array}$ & $\begin{array}{c}21 \\
(6.2)\end{array}$ \\
\hline Conflict Resolution & 338 & 3.32 & 1.52 & $\begin{array}{c}14 \\
(4.1)\end{array}$ & $\begin{array}{c}25 \\
(7.4)\end{array}$ & $\begin{array}{c}62 \\
(18.3)\end{array}$ & $\begin{array}{c}81 \\
(24.0)\end{array}$ & $\begin{array}{c}80 \\
(23.7)\end{array}$ & $\begin{array}{c}52 \\
(15.4)\end{array}$ & $\begin{array}{c}19 \\
(5.6)\end{array}$ & $\begin{array}{c}5 \\
(1.5)\end{array}$ \\
\hline Costs and Benefits & 337 & 4.84 & 1.51 & $\begin{array}{c}5 \\
(1.5)\end{array}$ & $\begin{array}{c}5 \\
(1.5)\end{array}$ & $\begin{array}{c}16 \\
(4.7)\end{array}$ & $\begin{array}{l}25 \\
(7.4)\end{array}$ & $\begin{array}{c}69 \\
(20.5)\end{array}$ & $\begin{array}{c}80 \\
(23.7)\end{array}$ & $\begin{array}{c}88 \\
(26.1)\end{array}$ & $\begin{array}{c}49 \\
(14.5)\end{array}$ \\
\hline Enforcement & 337 & 4.00 & 1.50 & $\begin{array}{c}6 \\
(1.8)\end{array}$ & $\begin{array}{c}19 \\
(5.6)\end{array}$ & $\begin{array}{c}23 \\
(6.8)\end{array}$ & $\begin{array}{c}60 \\
(17.8)\end{array}$ & $\begin{array}{c}97 \\
(28.8)\end{array}$ & $\begin{array}{c}81 \\
(24.0)\end{array}$ & $\begin{array}{c}39 \\
(11.6)\end{array}$ & $\begin{array}{c}12 \\
(3.6)\end{array}$ \\
\hline Equity & 338 & 3.37 & 1.65 & $\begin{array}{c}20 \\
(5.9)\end{array}$ & $\begin{array}{c}28 \\
(8.3)\end{array}$ & $\begin{array}{c}50 \\
(14.8)\end{array}$ & $\begin{array}{c}79 \\
(23.4)\end{array}$ & $\begin{array}{c}61 \\
(18.0)\end{array}$ & $\begin{array}{c}67 \\
(19.8)\end{array}$ & $\begin{array}{l}25 \\
(7.4)\end{array}$ & $\begin{array}{c}8 \\
(2.5)\end{array}$ \\
\hline Flexibility & 338 & 3.60 & 1.32 & $\begin{array}{c}6 \\
(1.8)\end{array}$ & $\begin{array}{c}13 \\
(3.8)\end{array}$ & $\begin{array}{c}48 \\
(14.2)\end{array}$ & $\begin{array}{c}85 \\
(25.1)\end{array}$ & $\begin{array}{c}107 \\
(31.7)\end{array}$ & $\begin{array}{c}52 \\
(15.4)\end{array}$ & $\begin{array}{c}25 \\
(7.4)\end{array}$ & $\begin{array}{c}2 \\
(.6)\end{array}$ \\
\hline Funding & 338 & 4.26 & 1.39 & $\begin{array}{c}2 \\
(.6)\end{array}$ & $\begin{array}{c}7 \\
(2.1)\end{array}$ & $\begin{array}{c}22 \\
(6.5)\end{array}$ & $\begin{array}{c}54 \\
(16.0)\end{array}$ & $\begin{array}{c}104 \\
(30.8)\end{array}$ & $\begin{array}{c}75 \\
(22.2)\end{array}$ & $\begin{array}{c}55 \\
(16.3)\end{array}$ & $\begin{array}{c}19 \\
(5.6)\end{array}$ \\
\hline Integration & 338 & 3.25 & 1.58 & $\begin{array}{c}17 \\
(5.0)\end{array}$ & $\begin{array}{c}37 \\
(10.9)\end{array}$ & $\begin{array}{c}48 \\
(14.2)\end{array}$ & $\begin{array}{c}76 \\
(22.5)\end{array}$ & $\begin{array}{c}87 \\
(25.7)\end{array}$ & $\begin{array}{c}47 \\
(13.9)\end{array}$ & $\begin{array}{c}22 \\
(6.5)\end{array}$ & $\begin{array}{c}4 \\
(1.2)\end{array}$ \\
\hline Knowledge & 338 & 4.00 & 1.41 & $\begin{array}{c}6 \\
(1.8)\end{array}$ & $\begin{array}{c}13 \\
(3.8)\end{array}$ & $\begin{array}{l}27 \\
(8.0)\end{array}$ & $\begin{array}{c}70 \\
(20.7)\end{array}$ & $\begin{array}{c}78 \\
(23.1)\end{array}$ & $\begin{array}{c}99 \\
(29.3)\end{array}$ & $\begin{array}{c}38 \\
(11.2)\end{array}$ & $\begin{array}{c}7 \\
(2.1)\end{array}$ \\
\hline Leadership & 338 & 3.49 & 1.45 & $\begin{array}{c}10 \\
(3.0)\end{array}$ & $\begin{array}{c}21 \\
(6.2)\end{array}$ & $\begin{array}{c}53 \\
(15.7)\end{array}$ & $\begin{array}{c}69 \\
(20.4)\end{array}$ & $\begin{array}{c}103 \\
(30.5)\end{array}$ & $\begin{array}{c}59 \\
(17.5)\end{array}$ & $\begin{array}{l}17 \\
(5.0)\end{array}$ & $\begin{array}{c}6 \\
(1.8)\end{array}$ \\
\hline Local Control & 338 & 3.73 & 1.46 & $\begin{array}{c}10 \\
(3.0)\end{array}$ & $\begin{array}{c}11 \\
(3.3)\end{array}$ & $\begin{array}{c}41 \\
(12.1)\end{array}$ & $\begin{array}{c}91 \\
(26.9)\end{array}$ & $\begin{array}{c}83 \\
(24.6)\end{array}$ & $\begin{array}{c}61 \\
(18.0)\end{array}$ & $\begin{array}{c}35 \\
(10.4)\end{array}$ & $\begin{array}{c}6 \\
(1.8)\end{array}$ \\
\hline Monitoring & 338 & 4.05 & 1.52 & $\begin{array}{c}4 \\
(1.2)\end{array}$ & $\begin{array}{c}17 \\
(5.0)\end{array}$ & $\begin{array}{c}36 \\
(10.7)\end{array}$ & $\begin{array}{c}57 \\
(16.9)\end{array}$ & $\begin{array}{c}84 \\
(24.9)\end{array}$ & $\begin{array}{c}80 \\
(23.7)\end{array}$ & $\begin{array}{c}47 \\
(13.9)\end{array}$ & $\begin{array}{c}13 \\
(3.8)\end{array}$ \\
\hline Proactive Planning & 338 & 3.80 & 1.48 & $\begin{array}{c}6 \\
(1.8)\end{array}$ & $\begin{array}{c}15 \\
(4.4)\end{array}$ & $\begin{array}{c}52 \\
(15.4)\end{array}$ & $\begin{array}{c}54 \\
(16.0)\end{array}$ & $\begin{array}{c}90 \\
(26.6)\end{array}$ & $\begin{array}{c}81 \\
(24.0)\end{array}$ & $\begin{array}{c}34 \\
(10.1)\end{array}$ & $\begin{array}{c}6 \\
(1.8)\end{array}$ \\
\hline Trust & 337 & 3.48 & 1.66 & $\begin{array}{c}19 \\
(5.6)\end{array}$ & $\begin{array}{c}24 \\
(7.1)\end{array}$ & $\begin{array}{c}54 \\
(16.0)\end{array}$ & $\begin{array}{c}62 \\
(18.4)\end{array}$ & $\begin{array}{c}74 \\
(22.0)\end{array}$ & $\begin{array}{c}74 \\
(22.0)\end{array}$ & $\begin{array}{c}20 \\
(5.9)\end{array}$ & $\begin{array}{c}10 \\
(3.0)\end{array}$ \\
\hline
\end{tabular}

\section{Step 7: Survey summary statistics}

Index scores for categories were formed by averaging responses for items across each category. For example, in the survey tool there are three items that measure proactive planning. The three items were added together and averaged to get the average score for proactive planning. Once average criterion scores were obtained for each survey, survey scores were added together and averaged to produce an overall score for each of the 15 water management survey criterion (see Table 3).

\section{QUANTITATIVE SURVEY RESPONSES}

In total, 1615 surveys were mailed, and 338 completed surveys were returned, generating a response rate of $21.0 \%$ (see Table 4 ). The main challenge faced during survey implementation was a lack of access to surface water users' addresses. This limited the survey's ability to accurately reflect the opinions of those who solely use surface water. It is, however, important to note that proportionally fewer people rely solely on surface water within Nebraska compared with those who use groundwater or those who use both surface water and groundwater. Although water use statistics for the study area alone are not readily available, $85 \%$ of all consumptive water withdrawals, i.e., water that is removed from available supplies without return to the water resource system, in the state are from groundwater versus only $15 \%$ from surface water (United States Geological Survey 2005). Further, groundwater-irrigated agriculture represents approximately $93 \%$ of the state's groundwater withdrawals, and surface waterirrigated agriculture represents 24\% (United States Geological Survey 2005). For this survey, there were a total of 319 responses from people who use groundwater or both groundwater and surface water, and $85 \%$ of all respondents indicated they use water for irrigation. Although it would have been optimal to obtain a higher response rate, particularly from surface water users, survey results are largely representative of the water user population within the study region.

\section{QUALITATIVE AND QUANTITATIVE RESULTS}

We assessed the general question of how well water users in the PRB think Nebraska's current water management system is working, using both quantitative and qualitative data collection. Interviews were conducted with a wide range of stakeholders within the PRB, whereas survey data were focused on surface 
Table 4. Water management survey demographic data.

\begin{tabular}{lcc}
\hline \hline & $\mathrm{N}$ & Percentage \\
\hline Type of Water Use & 143 & \\
Groundwater & 18 & 42.3 \\
Surface Water & 171 & 5.3 \\
Both & 6 & 50.6 \\
Missing & & 1.8 \\
Primary Water Use & 14 & \\
Domestic & 3 & 4.1 \\
Industrial & 204 & 0.9 \\
Irrigation & 20 & 60.4 \\
Livestock & 83 & 5.9 \\
Irrigation \& Livestock & 6 & 24.6 \\
Other & 8 & 1.8 \\
Missing & & 2.4 \\
Gender & 262 & 77.5 \\
Male & 54 & 16.0 \\
Female & 22 & 6.5 \\
Missing & & \\
Age & 61 & 18.0 \\
19-50 & 185 & 54.7 \\
51-70 & 90 & 26.6 \\
71 and over & 2 & 0.6 \\
Missing & & \\
\hline
\end{tabular}

water and groundwater right holders, who are subsequently referred to as water users. Consequently, qualitative interview data include a more diverse range of perspectives. With this in mind, qualitative and quantitative data were reviewed in tandem, revealing that for the majority of criteria both methods indicated similar trends in stakeholders' beliefs of how well management efforts are working. Results for each of the 15 success criteria (defined in Table 1) are presented below.

\section{Ability to influence rules}

Survey and interview responses both indicated that many stakeholders in the PRB perceive they have a limited ability to influence water-use rules. Survey responses reveal that the majority of survey respondents did not agree that they are able to influence rules (Table 3). Further, when splitting the responses into either disagree (rankings of 0-3) or agree (rankings of 4-7) categories, only $28.7 \%$ of respondents agreed they can influence rules, whereas $71.3 \%$ did not. Moreover, $10 \%$ of respondents ranked their ability to influence rules as 0 , indicating they have no ability to influence water-use rules under the current system. In-depth interviews with the wider stakeholder group corroborated these attitudes. A number of stakeholders, including municipal, environmental, and surface water interests, thought they have a limited ability to influence the decision-making process, do not always have a seat at the table, and can feel intimidated by water-user interests that they believe hold more weight, e.g., the belief that consumptive water uses hold more weight than environmental or municipal interests.

\section{Clearly defined water-use rules}

Quantitative survey findings show that, overall, water users felt that water-use rules are clearly defined. When split into agree and disagree categories, $68 \%$ of respondents agreed that rules are clearly defined, and $32 \%$ did not. Interview results display a similar trend. Although a few interviewees mentioned that the IMP framework is too vague, many stakeholders commented that this is, in fact, one of the benefits of the current system, because it allows NRDs to customize plans to best meet local needs. Numerous interviewees mentioned that NRDs play a vital role in communicating information and guidance on water-use rules to users and that NRDs are a valuable resource stakeholders can turn to if they have water-related questions or concerns.

\section{Conflict resolution}

Survey respondents indicated that the current management system is performing moderately well in devising adequate conflict resolution mechanisms to manage water, as seen by the largest response rate of 3 . When divided into agree and disagree categories, water users were relatively evenly split, with $46.2 \%$ indicating agreement that the system is working well and $53.8 \%$ feeling that it is not working well. Although conflict resolution did not evolve as a theme of successful management from stakeholder interviews, the criterion is one of Ostrom's eight design principles. Because sharp differences often exist in how people use and value resources, conflict is inherent in environmental choices (Dietz et al. 2003). Consequently, regular access to low-cost, rapid conflict resolution mechanisms is needed to mediate conflicts over the misinterpretation of rules of use (Ostrom 1990, Anderies et al. 2004). Several stakeholders did mention that if the DNR does not feel a local NRD is implementing and enforcing rules under their IMP, they can raise their concerns with the Integrated Water Review Board, a board appointed by the governor to resolve the dispute. However, to date this mechanism has not been used.

\section{Costs and benefits}

The largest percentage of respondents, $26.1 \%$, indicated that the benefits they receive from using water resources outweigh the costs of developing and managing the resource. Further, when split into agree and disagree categories, $84.9 \%$ of respondents indicated agreement that the benefits they get from using water outweigh their costs. Although costs and benefits did not arise as a theme in interview data, Elinor Ostrom (1990) listed this criterion as one of her eight design principles, recognizing that costs accrued in managing CPRs should be in line with the benefits received. Several stakeholders did mention that although an economic cost is associated with using, or not using, water for irrigation, there is not currently a cost associated with taking water out of the river or for associated ecosystem goods and services. Further, although water is a relatively inexpensive resource in many respects, several environmental stakeholders indicated it is a very expensive resource from a conservation standpoint.

\section{Enforcement}

Surveyed water users think the current water management system is working relatively well when it comes to enforcing water-use rules, as indicated by the largest response rate of 4 . When divided into agree and disagree categories, $68 \%$ of water users agreed the system is working well when it comes to enforcement, whereas $34 \%$ did not. Although enforcement did not emerge as a theme characteristic of successful water management among interviewees, Ostrom (1998) describes graduated sanctions in enforcing water rules as a close-to-universal characteristic in robust CPR institutions. Graduated sanctions are important 
because they maintain a sense of fairness by allowing flexible punishment (Anderies et al. 2004). Although enforcement was not extensively discussed during interviews, a handful of interviewees commented that penalties for not abiding by wateruse rules can range from a slap on the wrist to not being able to irrigate anymore, with various monetary fines and penalties possible in between.

\section{Equity}

Survey responses indicated that water users were roughly divided in their beliefs that all water interests have equal representation under the current management system; $47.6 \%$ of respondents agreed that the system is working in this regard, and $52.4 \%$ did not. The largest number of respondents ranked this criterion a 3, whereas $5.9 \%$ ranked it a 0 . Surveyed water users were somewhat split on this criterion, but many interviewees representing the wider stakeholder group voiced concerns that the current system is not always equitable when it comes to who holds the power over water management decisions, what interests are represented during the decision-making process, and where the responsibility lies in solving water quantity problems. Within the basin, feelings of inequity appear to be widespread and deep rooted, and to have historical connotations; however, numerous interviewees indicated that the IMP process is facilitating dialogue and bringing people together, which is building trust among stakeholders.

\section{Flexibility}

The greatest percentage of survey respondents $(31.7 \%$ or 107 people) believed that the current water management system is working relatively well when it comes to flexibility, as indicated by the dominant response ranking of 4 . When the responses were viewed in either agree or disagree format, respondents were roughly divided, with $55 \%$ agreeing the system is working well and $45 \%$ indicating is not working well. A number of interviewees explained that having a flexible water management system is imperative to address diverse and changing physical and hydrological conditions across the basin, as well as to inform the improvement of management strategies. Many interviewees discussed the value of the current IMP framework, which affords NRDs flexibility in tailoring management plans to best address local concerns and conditions. However, several stakeholders mentioned there is little flexibility in surface water use, which is governed by the law of prior appropriation: a first-in-time, firstin-right system. These interviewees reasoned that in an overappropriated basin, there is little flexibility when there is no new water available for use.

\section{Funding}

Surveyed water users indicated that Nebraska's water management system is working relatively well in terms of being sufficiently funded; $31.7 \%$ of respondents ranked this criterion as a 4 , and $74.9 \%$ indicated agreement that the system is working well. However, interviews revealed a somewhat different scenario. Although numerous stakeholders mentioned that the NRDs' taxing authority, albeit an authority with limits, is a beneficial characteristic of the NRD system, numerous interviewees discussed funding as a primary challenge in managing water resources, specifically in regards to securing continual funding to finance water projects, maintain staff, monitor resources, and fund new programs like IMPs. Although the taxing authority of
NRDs helps, in addition to state and federal funding sources, several stakeholders commented that taxing their way out of problems is not the ultimate answer. Nonetheless, as state and local agencies begin to work together through IMP initiatives, increased opportunities to leverage funding offer promise.

\section{Integration}

Interview and survey data revealed that stakeholders believe the water management system is working relatively well in terms of integration. The greatest number of survey respondents ranked this criterion a 4, while when split, $47.3 \%$ agreed the system is well integrated, and $52.6 \%$ did not. Further, $5.0 \%$ thought the current water management system is not at all integrated. Challenges to integration, as discussed by interviewees, arise out of Nebraska's bifurcated legal systems for managing surface water and groundwater, from maintaining different management agencies to govern often-interconnected water resources, and from the independent mind-set of Nebraska water users. Despite these challenges, which are largely a reflection of Nebraska's water management history, the majority of interviewees think the IMPs process is helping to overcome barriers by bringing agencies and stakeholders together in the planning process.

\section{Knowledge}

Water users reported relatively strong agreement that sufficient knowledge exists to successfully manage surface water and groundwater resources, because the greatest percentage of water users ranked knowledge a 5 on the survey scale. When divided into agree and disagree categories, $65.7 \%$ of respondents thought the system is working well when it comes to knowledge, and $34.3 \%$ did not. Conversely, although several interviewees acknowledged that water-related knowledge is constantly advancing, they believed that much uncertainty remains, specifically in relations to groundwater and surface water interactions. One interviewee reasoned that within Nebraska, the connection between surface water and groundwater was not legally acknowledged until 1996 and therefore it will take time to develop technical tools, to learn, and to educate stakeholders when there are problems to solve.

\section{Leadership}

According to survey responses, $54.7 \%$ of water users agreed and $45.3 \%$ disagreed that Nebraska's current water management institutions possess good leadership, with the largest number of respondents ranking this criterion a 4 , or working relatively well. Interviews, however, revealed that leadership in water management is one area in which the state struggles. Many stakeholders raised concern that management efforts often do not look at the big picture when it comes to managing water. Although water is a flowing resource that transcends boundaries, water management is often segmented, fails to set overarching goals, and is heavily influenced by political pressures. Numerous interviewees indicated that good leadership is essential to more comprehensively and effectively managing the state's wealth of water resources.

\section{Local control}

The greatest number of survey respondents thought the current system is performing moderately well when it comes to implementing locally devised rules for water management, giving this criterion a ranking of 3 . When split into agree/disagree categories, $53.7 \%$ agreed this success criterion is working well, 
and $43.7 \%$ did not. Interviews revealed that many stakeholders are strong supporters of local control and of Nebraska's innovative management system, which they believe allows districts to tailor management strategies to specific needs and bridge gaps between state agencies and local water users. However, a number of interviewees also voiced concern with the current system and the fact that NRD boards are dominated by agricultural interests, which are not necessarily representative of the diversity of stakeholder views within the basin. Consequently, although interviewees generally showed strong support for local control, there was concern that locally devised rules do not fully consider the range of stakeholder interests.

\section{Monitoring}

Survey data revealed management efforts are working relatively well when it comes to monitoring water resources. The largest response was a 4 on the survey scale, with $66.3 \%$ of respondents agreeing that monitoring efforts are working well. Although monitoring did not arise as a success criterion among stakeholders in the PRB, field studies have shown that monitoring is a vital characteristic in maintaining robust and successful CRP institutions (Ostrom 1998). Interviews did, however, reveal that throughout the PRB water-use monitoring practices vary considerably. A few NRDs require meters, whereas most do not; other monitoring efforts by agencies involve annual or semiannual low-level infrared photography used to ensure that farmers are complying with established limits on irrigating land. Although interviews revealed many differences in opinion regarding monitoring, more specifically toward water-use meters, several stakeholders discussed how metering within their NRD has become a positive factor for both water managers and users by increasing water-use knowledge. Actual facts, as they see it, are much more informative in substantiating management actions than rhetoric.

\section{Proactive planning}

Many water users believed that the current management system is working relatively well when it comes to proactive planning, with $26.6 \%$ ranking this criterion as a 4 . Furthermore, $62.4 \%$ of respondents agreed that the current management system is proactive, and $37.6 \%$ did not. On the other hand, interviews revealed that the wider stakeholder group generally thought that water resource institutions within the state are not very proactive. As reasoned by several interviewees, IMPs are only mandatory for basins that are declared fully appropriated or overappropriated and as a result are more reactive than proactive. Current efforts, although in their infancy, are heavily focused on the short-term goals of reducing water use rather than proactively planning to avoid future problems.

\section{Trust}

Water users were roughly split in how much they trust water management institutions within Nebraska. Survey results showed that $52.8 \%$ of water users trust the current water management system, and 47.8 do not. The largest percentage of respondents, $22 \%$, ranked this criterion as a 4 on the survey scale, whereas $5.6 \%$ of respondents indicated that they have no trust, a ranking of 0 , in the current system. Similar to survey results, interviews indicated that the wider stakeholder group also has mixed feeling when it comes to how much they trust the current system. A few interviewees discussed a history of mistrust between state and local agencies, arising in part out of local fears that the state would impose regulations not in their best interests. Limitations in stakeholders' ability to influence the rules, either because they do not have a seat at the table or because they feel that their concerns are not legitimately considered, also foster mistrust within the current system. However, many recognize that IMP efforts are working to alleviate some of this mistrust by forging better relationships between stakeholders throughout the basin.

\section{DISCUSSION AND RECOMMENDATIONS}

A notable limitation of the quantitative component of this study is that no benchmark by which to measure improvement or progress toward success exists. This raises two important points. First, this study demonstrates the value of assessing system performance, which can provide vital benchmarks and opportunities from which to learn. Second, it highlights the utility and importance of using qualitative data to inform quantitative data. In this study, qualitative data incorporate indispensable local and institutional knowledge that help to explain quantitative data results. This speaks to the value of using both qualitative and quantitative data to more robustly and comprehensively review system performance.

In this study, qualitative interviews reveal that the characteristics stakeholders think are vital to the successful management of water resources corroborate the CPR principles for institutional success established to date. Directly asking stakeholders about the components of successful water resource management yielded results similar to principles previously derived from field observations, laboratory experiments, and extensive literature reviews (Ostrom 1990, Baland and Platteau 1996, Wade 1998, Agrawal 2001, Pomeroy and McConney 2007). This is an interesting and notable finding given that the majority of stakeholders interviewed have little knowledge of such principles, which are largely written about in academic literature. Further, this research shows that success characteristics established to date based on small-scale ecologies and institutions (Dietz et al. 2003) appear to also be applicable at larger, more complex scales, i.e., they are applicable to Nebraska's water management institutions.

In using these principles to qualitatively and quantitatively assess how well Nebraska's water management institutions are working within the overappropriated portion of the $\mathrm{PRB}$, this research reveals that as a whole, the current system is working relatively well. Interview data and survey data showed similar trends in responses for many of the success criteria, including an ability to influence rules, clearly defined water-use rules, flexibility, integration, and local control. However, notable differences in views between interview and survey responses were seen for equity, funding, knowledge, leadership, proactive planning, and trust. Differences in views between the interviews and survey results are likely attributable to the populations for which the data are representative; interview data represent the wide diversity of stakeholder views within the PRB, whereas quantitative survey data represent only surface water and groundwater right holders within the basin.

Stakeholders generally feel that the biggest challenges faced by the current management system are related to their ability to influence water-use rules, equity, funding, knowledge, leadership, proactive planning, and trust. However, although interviewees recognized that there are definite challenges to overcome, there 
was general agreement that integrated management planning is moving the state closer to success. To remain on this path toward success, we recommend the following opportunities for continued improvement: (1) ensure all stakeholder interests are represented, (2) provide increased opportunities to participate, and (3) work toward more holistic and proactive water management, particularly through Integrated Management Planning.

In discussing these recommendations, it is important to note that the criteria presented in this research are often related, intertwined, and synergistic. For example, trust between water users and managers is not a given; trust is a process that takes time to develop and can be facilitated by the process of participation, confidence in leadership, and accurate and reliable information, i.e., knowledge. Therefore, our recommendations are not presented by individual criterion, but as more comprehensive recommendations that we believe will continue to strengthen the success of Nebraska's water management system.

\section{Ensure all stakeholder interests are represented}

Survey results indicate that water users are relatively split on how equitably they feel they are treated under the current management system. In-depth interviews representative of the larger stakeholder population reveal an even greater level of concern when it comes to how equitable the current system is. As revealed in interviews, problems with equity are diverse, deeply rooted in the history of water resources management within the state, and not easily solved.

The review by Syme et al. (1999) of fairness in water allocation lists some of the most important aspects of fairness of the allocation process: management of water for future generations, water as a public good and therefore being managed as such, the rights of the environment, and how efficiently water is being used. To ensure that the diverse views and values related to water allocation are represented, a necessary first step is arguably to ensure that all stakeholder interests are represented in the decision-making process.

Although the current IMP process does require consultation with broad stakeholder interests throughout the basin as identified by either the DNR or NRD (Neb Rev Stat \$46-715(5)(b)), many interviewees, specifically those representative of environmental and surface water interests, feel they do not always have a seat at the table when important water management decisions are being made. Many also think the NRD Board of Directors is dominated by agricultural interests and therefore not representative of the diversity of stakeholder concerns within the basin.

If stakeholder interests are not represented in the decision-making process, there remains limited opportunity to reconcile differences up front. By their very nature, participatory processes are meant to establish common ground and trust between participants and facilitate a better understanding of diverse stakeholder views (Stringer et al. 2006). Face-to-face interactions and communication have been repeatedly shown to increase the levels of cooperation achieved (Ostrom 1998), while also building trust and reciprocity between individuals and groups (Ostrom 1998, Dietz et al. 2003, Reed 2008). Although ensuring representation of water interests will by no means alleviate all equity issues within the basin, it is a necessary starting point in recognizing and reconciling diverse and often conflicting water interests.

\section{Increased opportunities to participate}

Both survey results and in-person interviews suggest that stakeholders in the PRB feel they have a limited ability to influence water-use rules. However, both stakeholder interviews and Ostrom's design principles agree that stakeholders must genuinely believe, at least to a certain extent, that they have the power to meaningfully influence water-use rules. As Parkins and Mitchell (2005) note, the public will not maintain an active interest in the planning processes without hope of influencing a decision or given situation.

Reed (2008) recommends that stakeholders can be empowered through participation by ensuring that participants have the power to really influence the decision and ensuring that participants have the technical capability to engage effectively with the decision. Stakeholders must be able to voice their concerns and engage in discussions shaping water-use rules, and their concerns must be legitimately considered. Moreover, an educational component is sometimes necessary to ensure that stakeholders understand, at least at a basic level, the technical aspects being considered in support of various management decisions.

Interviews also indicated that stakeholders want increased opportunities to voice issues and concerns after IMPs are established. Currently, there is one annual meeting between PRB NRDs and the DNR where stakeholders come together in the form of a public meeting. Interviewees described this gathering as more of an opportunity to report on current projects, rather than engage in meaningful dialogue about IMP progress, issues, and/or concerns. To facilitate increased opportunities to engage in meaningful participation, the format of this meeting could be restructured to promote more engaged learning and face-to-face discussion on management effectiveness to date, highlighting and devising strategies for continued improvements. Further, it is argued to be most effective, stakeholder participation must be institutionalized (Reed 2008). Creating an organizational culture where stakeholder input and feedback are encouraged and incorporated into the decision-making process can improve strides toward more successful water resources management.

\section{More proactive and holistic water management}

Within Nebraska, IMPs are required only if a basin is designated as fully appropriated or overappropriated. This methodology is a reactive, not proactive, approach to management. By the time the water resources within a given area are deemed fully appropriated or overappropriated, many options for more proactive management have already been foreclosed. At this point, managers are trying to decipher how to rectify the problem of unsustainable water use instead of trying to avoid the situation from the onset.

Although not mandatory, NRDs not currently designated as fully appropriated or overappropriated do have the option of pursuing voluntary IMPs. To date, 10 NRDs have implemented mandated IMPs, including 1 overarching basin-wide plan for the PRB (DNR 2013), and another 5 are working toward voluntary IMPs (DNR $2012 b$ ). However, that leaves 8 NRDs without current plans to implement or work toward IMPs. Under Nebraska's current water management system, this means that NRDs manage groundwater resources and the state DNR manages surface water resources, with little to no coordination. 
The IMP process offers a valuable opportunity to build relationships between stakeholders, facilitate shared learning, and proactively discuss water management challenges before they become a problem. Further, the process can stimulate innovative solutions and strategies geared toward better managing water resources. Several stakeholders mentioned wishing efforts focused on collectively managing water resources had started prior to 2004, when LB962 was passed, to avoid the problems now faced. However, stakeholders hope the PRB can serve as an example to other basins by encouraging them to avoid a similar situation.

Water, as a flowing and interconnected resource, should be managed as such. Therefore, the current management system should move beyond voluntary IMPs for individual NRDs toward IMPs for all NRDs, as well as overarching basin-wide plans for the larger watersheds. Additionally, to further promote holistic and proactive water resources management throughout the state, efforts to more uniformly and comprehensively monitor water resources should be pursued. Such efforts would not only increase the knowledge base of water resources within the basin but could inform efforts for more proactive water management. Increased integration, knowledge, and a heightened focus on more comprehensive water resources management will help the state move beyond a system of individual NRDs and closer to shared methodologies, goals, and objectives.

\section{CONCLUSION}

Without follow-up and investigation, resource managers and policy makers cannot be sure as to whether they have gotten the rules right. Improving resource managers' ability to learn about and better understand the implications of management approaches and policies is an essential component of natural resources management; such information reveals strengths and weaknesses of the current system, and if acted up, has the potential to lead to more successful resource management institutions.

Within the basin, stakeholders agree that movement toward more integrated management planning efforts is an important first step in building successful water management institutions within Nebraska. Overall, interviewees feel the right tools exist within the state to successfully manage water and now it is a matter of putting these tools into action. However, there is little doubt that this change will take time. Interviewees recognize that it has taken significant effort and resources to get to where there are and that change will not happen overnight. Having a baseline assessment of how well the current management system is working will be a key indicator in determining success in moving forward. Additionally, further research on how the assessment criteria interact and influence one another will also be essential in achieving a more robust understanding of institutional success and how to achieve it.

Responses to this article can be read online at: http://www.ecologyandsociety.org/issues/responses. $\mathrm{php} / 7367$

\section{Acknowledgments:}

The authors would like to thank Ann Bleed, Sandra Zellmer, Craig Allen, and Sheri Fritz for their input and expertise, which helped improve this research study. An earlier version of this manuscript was improved by insightful comments from two anonymous reviewers. C Hoffman Babbitt received support for this research through the NSF IGERT on Resilience and Adaptive Governance of Stressed Watersheds at the University of Nebraska-Lincoln (NSF \# 0903469) and from a Center for Great Plains Studies research grant.

\section{LITERATURE CITED}

Agrawal, A. 2001. Common property institutions and sustainable governance of resources. World Development 29:1649-1672. http://dx.doi.org/10.1016/S0305-750X(01)00063-8

Anderies, J. M., M. A. Janssen, and E. Ostrom. 2004. A framework to analyze the robustness of social-ecological systems from an institutional perspective. Ecology and Society 9(1): 18. [online] URL: http://www.ecologyandsociety.org/vol9/iss1/art18

Armitage, D., F. Birkes, and N. Doubleday. 2007. Adaptive comanagement: collaboration, learning, and multi-level governance. UBC Press, Vancouver, British Columbia, Canada.

Baland, J. M., and J. P. Platteau. 1996. Halting degradation of natural resources: is there a role for rural communities? Calrendon, Oxford, UK.

Berkes, F. 2007. Community-based conservation in a globalized world. Proceedings of the National Academy of Sciences of the United States of America 104:15188-15193. http://dx.doi. org/10.1073/pnas.0702098104

Creswell, J., and V. Plano Clark. 2011. Designing and conducting mixed methods research. Second edition. Sage, Thousand Oaks, California, USA.

DeVellis, R. 2003. Scale development: theory and application. Sage, Thousand Oaks, California, USA.

Dietz, T., E. Ostrom, and P. C. Stern. 2003. The struggle to govern the commons. Science 302:1907-1912. http://dx.doi.org/10.1126/ science. 1091015

Dillman, D., J. Smyth, and L. Christian. 2009. Internet, mail, and mixed-mode surveys: the tailored design method. Third edition. Wiley, Hoboken, New Jersey, USA.

Field, A. 2009. Discovering statistics using SPSS. Third edition. Sage, Thousand Oaks, California, USA.

Folke, C., L. Pritchard, Jr., F. Berkes, J. Colding, and U. Svedin. 2007. The problem of fit between ecosystems and institutions: ten years later. Ecology and Society 12(1): 30. [online] URL: http:// www.ecologyandsociety.org/vol12/iss1/art30/

Fowler, F. J. 1995. Improving survey questions: design and evaluation. Sage, Thousand Oaks, California, USA.

Hatch, J. 2002. Doing qualitative research in education settings. State University of New York Press, Albany, New York, USA. 
Johnson, R. B., A. Onwuegbuzie, and L. A. Turner. 2007. Toward a definition of mixed methods research. Journal of Mixed Methods Research 1(2):112-133. http://dx.doi.org/10.1177/1558689806298224

Lee, K. N. 1993. Compass and gyroscope: integrating science and politics for the environment. Island Press, Washington, D.C., USA.

Mossman, S. D. 1996. "Whiskey is for drinkin' but water is for fightin' about": a first-hand account of Nebraska's integrated management of ground and surface water debate and the passage of LB 108. Creighton Law Review 30:67-103.

Nahm, A. Y., S. S. Rao, L. E. Solis-Galvan, and T. S. RagunNathan. 2002. The q-sort method: assessing reliability and construct validity. Journal of Applied Statistics 1:114-125.

Nebraska Department of Natural Resources (DNR). 2005. What is the meaning of LB962's fully appropriated basin designation? DNR, Lincoln, Nebraska, USA.

Nebraska Department of Natural Resources (DNR). 2009. Fully appropriated and overappropriated surface water in Nebraska: determinations made by the Department of Natural Resources as of April 8, 2009. DNR, Lincoln, Nebraska, USA.

Nebraska Department of Natural Resources (DNR). $2012 b$. Natural resources districts initiating voluntary integrated management plans. DNR, Lincoln, Nebraska, USA.

Nebraska Department of Natural Resources (DNR). $2012 a$. Summary report: registered groundwater wells by natural resources district. Databank online. DNR, Lincoln, Nebraska, USA.

Nebraska Department of Natural Resources (DNR). 2013. Integrated water management-approved plans webpage. DNR, Lincoln, Nebraska, USA.

Nunnally, J. C. 1978. Psychometric theory. Second edition. McGraw-Hill, New York, New York, USA.

Ostrom, E. 1990. Governing the commons: the evolution of institutions for collective action. Cambridge University Press, Cambridge, UK. http://dx.doi.org/10.1017/CBO9780511807763

Ostrom, E. 1998. A behavioral approach to the rational choice theory of collective action. Presidential Address, American Political Science Association, 1997. American Political Science Review 92(1):1-22. http://dx.doi.org/10.2307/2585925

Ostrom, E. 2007. A diagnostic approach for going beyond panaceas. Proceedings of the National Academy of Sciences of the United States of America 104:15181-15187. http://dx.doi. org/10.1073/pnas.0702288104

Ostrom, E., J. Burger, C. B. Field, R. B. Norgaard, and D. Policansky. 1999. Revisiting the commons: local lessons, global challenges. Science 284:278-282. http://dx.doi.org/10.1126/ science.284.5412.278

Parkins, J. R., and R. E. Mitchell. 2005. Public participation as public debate: a deliberative turn in natural resource management. Society \& Natural Resources 18:529-540. http://dx. doi.org/10.1080/08941920590947977
Pomeroy, R., and P. McConney. 2007. Conditions for successful fisheries co-management in the wider Caribbean. Proceedings of the Gulf and Caribbean Fisheries Institute 58:62-65.

Poteete, A., M. Janssen, and E. Ostrom, editors. 2010. Working together: collective action, the commons, and multiple methods in practice. Princeton University Press, Princeton, New Jersey, USA.

Reed, M. S. 2008. Stakeholder participation for environmental management: a literature eview. Biological Conservation 141:2417-2431. http://dx.doi.org/10.1016/j.biocon.2008.07.014

Spector, P. E. 1992. Summated rating scale construction. Sage, Thousand Oaks, California, USA. http://dx.doi. org/10.4135/9781412986038

Stringer, L. C., A. J. Dougill, E. Fraser, K. Hubacek, C. Prell, and M. S. Reed. 2006. Unpacking "participation" in the adaptive management of social-ecological systems: a critical review. Ecology and Society 11(2):39. [online] URL: http://www. ecologyandsociety.org/vol11/iss2/art39/

Syme, G. J., B. E. Nancarrow, and J. A. McCreddin. 1999. Defining the components of fairness in the allocation of water to environmental and human uses. Journal of Environmental Management 57(1):51-70. http://dx.doi.org/10.1006/jema.1999.0282

Thomas, D. M., and R. T. Watson. 2002. Q-sorting and MIS research: a primer. Communications of the Association for Information Systems 8:141-156.

United States Geological Survey. 2005. Water use, by category of use, in Nebraska, 2005. United States Geological Survey, Reston, Virginia, USA. [online] URL: http://ne.water.usgs.gov/infodata/ wateruse/waterusecategory.html

Wade, R. 1998. Village republics: economic conditions for collective action in South India. ICS, Oakland, California, USA. 